\title{
In gesprek met Johan Heyns 1
}

W D Jonker

\section{ABSTRACT}

\section{In conversation with Johan Heyns}

The author commends Professor Heyns for his enormous contribution to the Reformed theology in South Africa. Heyns opted for a dynamic and inspiring theology of the Kingdom of God, which calls forth a response of obedience from all believers. However, the author is of the opinion that the philosophical character of the theology of Heyns, and especially his allegiance to the philosophy of Stoker in which the concept of the creation plays a dominant role, has hampered his possibility to develop a profound exegetical and Christological theology that could be critical enough of the kind of heresies which threatened the church during the apartheid era. He nevertheless praises Heyns for the role he has played in the recent changes within the church and suggests that he may indeed have made some adjustments as far as certain mistakable implications of his theology are concerned.

\section{'N GAWE AAN DIE KERK}

By 'n geleentheid soos hierdie moet 'n mens min of meer die balans opmaak van die bydrae wat ons geslag teoloë tot kerk en teologie gemaak het. En dan dink ek dat dit vir weinig teenspraak vatbaar is dat Johan Heyns 'n gawe aan ons kerk en teologie was. Hy is een van die vernaamste, indien nie dié vernaamste teoloog van ons geslag nie. In elk geval is hy die vrugbaarste teoloog wat die Afrikaanse gemeenskap nog opgelewer het.

Met die inset van sy hele dinamiese persoonlikheid en sy vurige liefde vir die teologie het hy ' $n$ nuwe era in die beoefening van die dogmatiek en etiek in ons land laat aanbreek. Die lang lys van sy publikasies is 'n aanduiding van die entoesiasme waarmee hy homself aan die teologie gewy het. Die omvang van sy belesenheid is verstommend, soos blyk uit die notas en verwysings in sy boeke. Hy het in erns toegetree tot die gesprek met die eietydse teologiese denke en hom in verskeie publikasies daarmee besig gehou. Hy besit 'n merkwaardige vermoë om die denke van andere beknop en helder weer te gee. Wat daarby opval, is dat hy nie, soos dit dikwels in die verlede by ons gebruiklik was, alles wat van buite die enger gereformeerde kring afkomstig was, by voorbaat negatief beoordeel nie. Hy kan ook die standpunte van diegene met wie hy verskil, simpatiek lees en regtig probeer verstaan. Hy kan op allerlei punte instemming met bepaalde aspekte van 
die nuwe teologiese strominge betuig en daarby aansluit. Die opset van sy eie teologie as geheel genome, is nie polemies nie, maar teties.

Dit is nie vreemd dat sy werk wye erkenning geniet nie. In die binneland is sy werk meermale eervol bekroon, maar ook ver buite die grense van ons land word hy as dogmatikus hoog geag. Dit is bekend dat sy Dogmatiek aan 'n Nederlandse teologiese fakulteit as handboek voorgeskryf is, en in verskeie nagraadse studies is sy werk in behandeling geneem.

DIE VISIOEN

Sy groot bydrae tot die Afrikaanse teologie is egter dat hy 'n eie teologiese denksisteem ontwikkel het. Betreklik vroeg in sy teologiese loopbaan het hy reeds 'n teologiese paradigma ontwikkel waaraan hy deurgaans verder getrou gebly het. Spore daarvan mag reeds vroeër by hom aanwesig gewees het, maar dit is tog in die besonder in sy werke wat sedert die helfte van die sestiger jare verskyn het, dat hy 'n bepaalde teologiese denkmodel ontwikkel het. Dit is opmerklik dat dit juis in 'n tyd gebeur het waarin hy homself met die nuwe teologie besig gehou en verskillende studies daaroor gepubliseer het. Dit het vir hom kennelik die waarde gehad dat hy sy eie posisie in dialoog met andere duideliker kon omlyn. Die vernaamste publikasies wat hier genoem moet word, is Die evangelie in krisis (1966), Denkers deur die eeue (1967) en Sterwende Christendom? (1969).

Die gesprek met moderne teoloë het Heyns daarvan oortuig dat daar behoefte is aan 'n dinamiese eietydse teologie wat op die vrae en tendense van die moderne era kan ingaan. Uiteraard het hy nie die gereformeerde teologie as sodanig as nie meer geskik vir die moderne wêreld beskou nie - daarvoor was hy deur sy agtergrond en opleiding te diep van die Calvinisme deurdronge - maar dit het vir hom gegaan om 'n nuwe teologiese aanpak wat die waarheid van die gereformeerde belydenis, of miskien is dit meer korrek om te sê: die waarheid van die Calvinistiese grondoortuigings, in die taal en idioom van die moderne tyd tot uitdrukking kon bring. Teen ongeveer 1970 het hy klaarblyklik tot groter helderheid hieroor gekom. Sy definitiewe posisie word dan uitgespel in die publikasies Die nuwe mens onderweg (1970) en Lewende Christendom: 'n teologie van gehoorsaamheid (1972). Die basiese konsep van sy teologie word goed geskets in die proefskrif van D F Theron, Die koninkryk van God in die teologie van J A Heyns (1984), maar is deur homself ook beknop saamgevat in sy artikel oor ' $n$ Teologie van gehoorsaamheid in die feesbundel vir Berkouwer, Septuagesimo Anno (1973,74-85).

Waarna Heyns gesoek het, was"n eietydse teologie wat in staat sou wees om onder één sentrale begrip die dinamiese wedersydse betrokkenheid van God en mens op mekaar tot uitdrukking te kon bring, en wel so, dat die inisiatief van God en die reaksie van die mens in die geskiedenis van hulle omgang met mekaar tot 
uitdrukking kan kom. Dit vind hy in die sentrale begrip van die koninkryk van God, met as immanent-subjektiewe korrelaat daarvan die menslike gehoorsaamheid ${ }^{2}$. In sy keuse vir die konsep van die koninkryk van God neem Heyns 'n wesenlik karakteristieke intensie van die gereformeerde teologie op: dat dit in die ware religie nie in die eerste plek om die mens en sy heil gaan nie, maar om die eer, heerlikheid en inisiatief van die lewende God 3 . Net so hang sy keuse vir die begrip gehoorsaamheid saam met die gereformeerde liefde vir die wet van God en die gevolglike klem op die heiliging van die ganse lewe as vrug van die regverdiging 4 . Heyns neem daarmee sy posisie in die hart van die gereformeerde verstaan van die heil in. Hy lê daarby egter eie aksente. Wat hom veral in die kombinasie van die begrippe koninkryk van God en gehoorsaamheid boei, is dat daarin tot uitdrukking kom dat die heerskappy van God geen dwang is nie, maar op sodanige wyse uitgeoefen word, dat die mens in sy gehoorsaamheid wesenlik 'n deel uitmaak van die wyse waarop God regeer, omdat die mens in 'n dialogiese verhouding met God staan en dus korrelatief by sy heerskappy betrokke is.

Ek meen dat hierdie visie wat sy hele teologie beheers, gebore is uit 'n verbinding van twee sterk invloede wat in sy akademiese vorming op hom uitgeoefen is: die wysbegeerte van Stoker en die dogmatiese metode van Berkouwer. Die wyse waarop hy die koninkryk verstaan, kan van Stoker afkomstig wees, maar in die uitwerking daarvan merk ek die invloed van Berkouwer. Hy was nie verniet 'n student van Berkouwer nie. Berkouwer het in sy teologie homself afgegrens van die idee van 'n polêre verhouding tussen God en mens soos dit agter soveel skeefgroei in dogmatiek en geloofsverstaan aanwesig is. Hy kies dan vir die figuur van die korrelasie tussen geloof en openbaring of geloof en genade, wat beteken dat die mens altyd in geloof en gehoorsaamheid korrelatief betrokke is op die genadeinisiatief van God en so juis as mens in 'n personele verhouding tot God ten volle tot sy reg kom. Dit geskied egter op sodanige wyse dat alle verdienstelikheid aan die kant van die mens uitgeslote is 5 , terwyl die menslike antwoord op Gods belofte en daad tog deurgaans as noodsaaklik en van beslissende betekenis verstaan kan word. God skakel die mens by sy handeling in deurdat Hy die mens vrymak en in staat stel om in die geloof te ontvang wat God gee en te doen wat God vra.

Hierby sluit Heyns aan. Deur die konsepte van die koninkryk van God en die menslike gehoorsaamheid korrelatief op mekaar te betrek, is dit vir hom moontlik om enersyds aan die inisiatief van God in die verwerkliking van sy raadsplan vas te hou, maar aan die ander kant die mens ten volle daarby in te skake ${ }^{6}$. So kan hy die gehoorsame mens werklik as medewerker van God in die koms van die koninkryk sien, sonder egter dat dit beteken dat die mens op enige wyse daarin selfstandig is en as 't ware teenoor God te staan kom. Dit is teen hierdie agtergrond dat Heyns met soveel oortuiging kan praat oor die bondgenootskaplike en dialogiese struktuur van die verhouding tussen God en mens, konsepte 
wat veral vir sy Skrifbeskouing van deurslaggewende betekenis is ${ }^{7}$. Dit is duidelik watter geweldige sedelike appél daaruit kan voortvloei. Sy teologie het dan ook'n sterk etiese karakter, en 'n mens kan jou selfs moeilik van die indruk losmaak dat hy in sy werke oor die etiek meer in sy element is as in sy dogmatiek.

In die meeste van sy publikasies sedert hy vir die eerste keer sy koninkryks- en gehoorsaamheidsteologie helder geformuleer het, sou hy dit telkens weer as vertrekpunt verduidelik. Dit geld van sy boek oor die Skrifvraagstuk, Brug tussen God en mens (1973), sy boek oor die kerk (1977) en sy Dogmatiek (1978). Dit is ook die strukturele basis van sy werke oor die etiek, en dit word selfs in sy laaste groter werk, Inleiding tot die dogmatiek (1992), herhaal. Dit word vir hom die omvattende kader waarbinne hy die ganse werklikheid sien en in die lig waarvan hy die ganse Skrif interpreteer. Maar dit is meer: dit is vir hom primêr 'n visioen wat sy werk deurdring en rig: die visioen van die koninkryk van God wat gerealiseer word langs die weg van gehoorsaamheid. Daarom draai alles. Daarin word alles saamgevat. Wanneer hy daaroor skryf, word sy taal vol besieling en dikwels feitlik digterlik. Dit is duidelik dat hy deur die visioen van die koninkryk en die betrokkenheid van die geskape werklikheid daarop sodanig geboei is, dat dit homself met vreugde vervul en hom daartoe dring om met entoesiasme van die heerlikheid daarvan te getuig. Dit kan verklaar waarom daar in die teologie van Heyns so 'n sterk positiewe toon aanwesig is, wat soms 'n byna doksologiese karakter aanneem.

\section{WYSGERIGE RAAMWERK}

Berkouwer het meermale die uitdrukking gebruik dat elke voëltjie sing soos hy gebek is. Daarmee het hy bedoel dat elke teoloog verskillend is en sy eie styl en metode sal ontwikkel. Dit geld uiteraard ook van Heyns. Dat sy styl en metode geslaagde resultate gehad het en ons teologie op 'n besondere wyse gedien het, is sonder meer waar. Sy teologie besit ' $n$ bepaalde skoonheid en ek kan my voorstel dat dit vir talle studente ' $n$ verrassende venster op die Skrif en die lewe in diens van God geopen het. Dit sluit egter nie uit dat daaroor ook krities geoordeel moet word en dat bepaalde vrae in verband daarmee gestel kan word nie.

Heyns wou kennelik niks anders as 'n behoudende gereformeerde teoloog wees nie. Die spore van die dogmatiek van Bavinck is oral by hom aanwesig. Ek het reeds op die invloed van Berkouwer op hom gewys. Dit is waarskynlik dat ook Berkouwer se openheid vir nuwe teologiese ontwikkelinge hom geïnspireer het. Veral in sy leer oor die Skrif en die uitvèrkiesing is beïnvloeding deur Berkouwer sigbaar. 'n Mens kan ook die invloed van Barth op bepaalde aspekte van sy denke aantoon ${ }^{8}$. Tog is die grootste invloed op Heyns se denke ongetwyfeld uitgeoefen deur die Christelike wysbegeerte van Stoker. In sy genoemde proefskrif toon 
Theron aan dat Heyns se koninkryksteologie tot op groot hoogte die teologiese vergestalting van die wysbegeerte van sy leermeester Stoker is 9 . Stoker se Wysbegeerte van die Skeppingsidee het aan hom die raamwerk verskaf waarbinne hy sy teologie kon ontwikkel. Dit het 'n beslissende invloed op die struktuur van sy denke gehad. Sy dogmatiek het basies 'n wysgerige onderbou, anders as byvoorbeeld dié van Adrio König wat 'n duidelike eksegetiese onderbou het. Al stel Heyns die konsep van die koninkryk sentraal in sy teologie, dink hy tog in werklikheid vanuit ' $n$ wysgerige visie op die skepping. Die vrae wat ek in verband met sy teologie wil stel, het in groot mate hierop betrekking.

Heyns se sterk wysgerige inset kan verklaar waarom hy die begrip van die koninkryk nie eksegeties ontwikkel het nie, maar as 'n dogmatiese verstaanskader vir die Skrif hanteer, en wel op sodanige wyse, dat die hele verhouding tussen God en sy skepping binne die konteks van die koninkryk verstaan word. Hy veroorloof homself om heeltemal verby te gaan aan die intensiewe diskussie wat in die NuweTestamentiese wetenskap rondom die begrip van die Ryk van God plaasgevind het. Om die waarheid te sê, hy gaan ook 'n eie weg deur die begrip van die koninkryk tot die skepping terug te voer - iets wat vreemd is aan die wyse waarop dié begrip in die Bybel self en in die geskiedenis van die gereformeerde teologie funksioneer. Ook ander gereformeerde teoloë het aan die koninkryk 'n sentrale plek in hulle denke gegee, maar dan het hulle dit meestal met die heil verbind, met die koms van die bevrydende en verlossende heerskappy van God in die sondige wêreld. Daardeur kon hulle beter as Heyns tot uitdrukking bring dat die koninkryk van God 'n eskatologiese konnotasie het. 'n Goeie voorbeeld hiervan is Van Ruler, op wie se werk ons hier egter nie verder kan ingaan nie ${ }^{10}$. Theron ${ }^{11}$ trek daaruit die konklusie dat Heyns se verstaan van die koninkryk van God nie uit sy omgang met die gereformeerde teologie gebore is nie, maar direk na Stoker teruggevoer moet word. Vir hom is die koninkryk 'n allesoorkoepelende uitdrukking vir Gods heerskappy oor skepping en geskiedenis, wat uiteindelik in Gods finale triomf sal oorgaan (1 Kor 15:28). Hierdie visie beskryf hy met groot teologiese flair en dit help hom om met verrassende insigte na vore te kom. (Aan die ander kant bring sy konsentrasie daarop ook 'n sekere beperking in sy teologie mee. Sedert die begin van die sewentiger jare het daar min aan sy teologie verander, ondanks die sterk kwantitatiewe groei van sy oeuvre).

Die gebruikmaking van wysgerige konsepte as sodanig hoef nie sonder meer negatief beoordeel te word nie. Geen teoloog kan ooit heeltemal aan die invloed van die wysbegeerte ontkom nie, al is dit alleen maar dat hy nie anders kan as om van wysgerige terme gebruik te maak nie. 'n Mens kan redeneer dat aansluiting by 'n Christelike wysbegeerte wat self stcrk teologiese elemente bevat, in 'n sin selfs voor die hand liggend kan wees. Die groot vraag is egter watter invloed daardie wysbegeerte op die teologie verkry. As dit ongemerk die plek van die 
eksegetiese grond van die dogmatiek inneem, of meebring dat die teologie self ingebed word in die filosofiese sisteem, kan dit daartoe lei dat die teologie nie meer, soos Berkouwer gesê het, binne die grense van die Skrif bly nie, maar'n kader word wat op die Skrif gelê word. Of dit kan lei tot 'n bepaalde seleksie van die Skrifgegewens wat in die teologie hanteer word. In albei gevalle word die eksegetiese basis van die teologie versmal, terwyl dit die bewegingsvryheid van die teologie ook aan bande kan lê.

Ek sê nie dat dit sonder meer in die teologie van Heyns gebeur nie, maar 'n mens moet tog bepaalde vrae in dié verband stel. So sou 'n mens met reg kon vra of sy aansluiting by die wysbegeerte van Stoker hom nie gekortwiek het in sy poging om 'n eietydse teologie te ontwerp wat tot die moderne mens kan spreek nie. Dit hoef nie die geval te gewees het as hy hoofsaaklik met die idee van die dialogiese struktuur van die verhouding tussen God en mens sou gewerk het, wat hy in aansluiting by Berkouwer se korrelasie-idee ontwikkel het nie. Ook ander studente van Berkouwer het hierdie lyn met 'n mate van sukses gevolg deur die bondgenootskaplike aard van die verhouding tussen God en mens te beklemtoon ${ }^{12}$. Maar die konsepte van skepping, wet en gehoorsaamheid wat Heyns aan Stoker ontleen het en wat ' $n$ sentrale plek in sy teologie inneem, kon nie op sodanige wyse tot die moderne mens se verbeelding spreek, dat dit die basis kon vorm vir 'n inspirerende en werwende nuwe kyk op die evangelie nie. Daarvoor adem hulle te veel in 'n ander geestesklimaat as die Westerse mens na die sestigerjare.

Heyns self skryf in die feesbundel vir Berkouwer: "Toegegee: gehoorsaamheid sal waarskynlik by die geestesinstelling van die moderne mens weinig aanklank vind. Die begrip dui op gesag en met name gesag wat van buite die mens appellerend op hom afkom. En juis dié aspek sal indruis teen die selfbepaling en die vryheidsideaal van die moderne mens met sy anti-outoritatiewe instelling. Teenoor hierdie bedenking kan egter gestel word dat die kategorie van gehoorsaamheid as uitdrukking van die afhanklikheidsbetrekking van die mens teenoor God of sy gode, mét al sy historiese nuanseringe, so seer eie is aan alle godsdienste dat dit die moeite loon om gehoorsaamheid ook binne die Christelike godsdiens as boodskap vir die mens van ons dag te ondersoek"13.

Hierdie aanhaling is om meer as een rede betekenisvol. Hier wys ek egter net daarop dat dit toon dat Heyns self besef het dat sy teologiese inset teen die gees van die tyd ingegaan het. Die soort wysgerige agtergrond waaruit hy dink, was vir die na-oorlogse mens met sy eksistensialistiese lewensbesef nie relevant nie. Op sigself hoef dit 'n teoloog nie te verbaas dat die moderne mens van elke tyd 'n ander verwysingsraamwerk as die Bybel het nie. 'Maar dit is begryplik dat 'n teoloog wat sy hart daarop sit om 'n eietydse teologie te ontwikkel en daarvoor sterk teen ' $n$ bepaalde wysgerige konsep aanleun, rekening sal moet hou met die denkwyse van sy tyd. Dan word die verskil in wysgerige raamwerk by die teoloog en die mense van sy 
tyd 'n faktor van belang. In hierdie lig gesien het Heyns se aansluiting by die wysbegeerte van Stoker waarskynlik 'n negatiewe rol gespeel. Stoker se wysbegeerte gebruik 'n konseptuele raamwerk wat mense in die vooroorlogse wêreld en miskien nog in die Suid-Afrika van kort ná die oorlog kon aanspreek, maar wat dit in die nuwe geestesklimaat van die sestigerjare nie meer op dieselfde wyse kon doen nie. Heyns se aansluiting daarby het dit waarskynlik vir hom moeiliker gemaak om, soos hy graag wou, 'n woord op sy tyd ${ }^{14}$ te spreek wat in wyer kringe gehoor kon word.

\section{'n Beskrywende teologie}

Daar is egter' $n$ tweede vraag wat gestel kan word. Dit is die vraag of die wysgerige aard van sy tipe teologie nie die kritiese snykant daarvan verminder nie. Sy teologie neig daartoe om op die basis van 'n omvattende sig op die werklikheid 'n beskrywende, analiserende en assertoriese karakter aan te neem. Dit bied 'n verklaring van die hele werklikheid en die geskiedenis sub specie Dei of sub specie aeternitatis. In 'n grootse visioen span dit 'n boog tussen proton en eskaton. Dit suggereer 'n oorkoepelende heelheid waarby alles êrens inpas en ondanks die versteuring van die sondeval na die uiteindelike triomf van die koninkryk op pad is. Daartoe dra alles by. Selfs die duiwel, die sonde en die kwaad is ondanks hulleself ingeskakel in en dienstig aan die onstuitbare gang van die koninkryk na die groot heerlikheid wat kom 15 .

Die gevaar van hierdie soort teologie is dat dit die sonde en die kwaad nie ernstig genoeg opneem nie. In 'n bepaalde sin word dit 'n theologia gloriae, nie 'n theologia crucis nie. Dit is nie 'n kritiese nie, maar 'n ponerende teologie, selfs 'n triomfantelike teologie. Theron ${ }^{16}$ is van mening dat die versteuring wat die sonde aangebring het, deur Heyns nie diepgaande genoeg gesien word nie. Daarom vergelyk hy die koninkryk van God by Heyns met 'n massiewe, onwrikbare entiteit wat soos 'n rotsblok teen 'n berg afval en kragtens God se soewereine almag, met of sonder die medewerking van die mens, tot sy doel kom. Dit is seker nie 'n gelukkige of billike beeld nie, omdat dit tot die wese van Heyns se teologie behoort dat hy juis die antwoord en gehoorsaamheid van die mens by die koms van die koninkryk in berekening bring. Maar die element van waarheid daarin is dat daar ' $n$ triomfantelikheid in sy teologie ingebou is wat alles by voorbaat bepaal en daarom nie genoeg van die werklike stryd en pyn rondom die sonde en die demoniese en menslike weerstand na vore laat kom nie.

Hierdie soort kritiek kom neer op die vraag of die kruis genoeg in die teologie van Heyns kan funksioneer. 'n Mens dink hier aan die kritiek wat Noordmans indertyd teen die soort teologie van Kuyper, maar veral van Schilder uitgespreek het. Hy tipeer dit as 'n vorm van kultuurteologie, omdat dit basies van die skepping en die kultuur uitgaan. Die aksent val daarin nie op die verlossing van 
sonde en skuld nie, maar op die herstel van die skepping en die ontwikkeling van die kultuur. Die eintlike heilsgebeure waarvan die Skrif getuig, is dan slegs 'n middel tot die doel om die kragte van die skepping wat onder die drumpel van die sonde gelê en wag het, weer in hulle oorspronklike geskapenheid te laat ontwik$\operatorname{kel}^{17}$. So word die aandag vanaf die kruis na die skepping verskuif. Dit kan maklik tot gevolg hê dat die evangelie van verlossing in die teologie plek maak vir 'n kultuurfilosofiese visie. Dit sou onjuis wees om hierdie kritiek sonder meer op Heyns van toepassing te maak. Wel kan 'n mens sê dat sy denke vanuit die skepping tot gevolg het dat die afgrondelikheid van die sonde en die kwaad onderbeklemtoon word in die lig van die sonnige, helder en positiewe visioen wat hy koester.

Dat hierdie soort teologie iets fassinerends bevat, kan nie betwyfel word nie. Heyns bevind homself ook in vername geselskap wat dit betref. Niemand minder nie as Karl Barth het, na sy aanvanklike kritiese inset, uiteindelik ook 'n triomfantelike teologie vanuit sy Christologiese konsentrasie ontwikkel ${ }^{18}$. 'n Mens sou selfs kon sê dat waar daar by Barth Christus staan, daar staan by Heyns die koninkryk. Tussen Heyns en Barth is daar groot verskille. Die basis van hulle denke is totaal verskillend. Heyns dink nie universalisties soos Barth nie. Hy is ook nie op dieselfde wyse modern as Barth nie. Barth sou weer nooit soos Heyns vanuit die skepping kon dink nie. Tussen hulle gaap die afgrond van die teologiese liberalisme, waardeur Barth wel heengegaan het, maar Heyns nie. Maar dit neem niks daarvan weg nie, dat daar 'n formele ooreenkoms tussen hulle teologieë is. In die teologie van Heyns is daar, soos in dié van Barth, 'n element van deursigtigheid, omdat ' $n$ bepaalde sleutel hanteer word om die inhoud van die Skrif oop te sluit. En dan blyk dit dat die inhoud van die Skrif lig is en nie duisternis nie, triomf en nie nederlaag nie. Deur hierdie visie word die kritiese sig op die erns van die kwaad en die aardse stryd verminder.

\section{Die antitese}

Hiermee hang 'n derde vraag saam wat 'n mens in verband met Heyns se teologie moet stel. Dit is of sy denke vanuit die skepping hom nie verhinder het om van die begin af krities genoeg teenoor die volksteologie te wees wat so lank in die Afrikaanse kerke amok gemaak het nie. Dit spreek vanself dat daar 'n kategoriale kloof tussen Heyns se wysgerige teologie en die volksteologie bestaan ${ }^{19}$. Dit neem egter nie weg nie, dat hy met konsepte werk en 'n dinkraamwerk hanteer waarby aanhangers van die volksteologie aansluiting kon vind. So is dit met name opvallend watter groot plek die volk in die teologie van Heyns inneem en hoe dikwels dit in verband gebring word met die verskeidenheid wat met die skepping gegee is. Dit is waar dat baie van die dinge wat Heyns hieroor skryf, op sigself en in abstracto korrek kan wees. Hy probeer ook deurgaans om deur afgrensings en 
kwalifikasies 'n duidelike afstand te bewaar van die konklusies wat in die volksteologie uit die skeppingsmatige verskeidenheid getrek word. Maar onder die konkrete historiese omstandighede waarin Heyns in hierdie land as teoloog van aansien gewerk het, was die antitese tussen sy teologie en die volksteologie nie vir die gemiddelde mens duidelik genoeg nie.

Dat Heyns in 'n tyd toe die begrip volk in die Afrikaanse politieke en kulturele lewe oorspan is, in sy teologie ook soveel oor die volk kon skryf en dit selfs 'n gestalte van die koninkryk naas die kerk kon noem ${ }^{20}$; en dat hy in 'n tyd toe apartheid met die argument van die skeppingsverskeidenheid verdedig is en die eenheid van die kerk en die gemeenskap van die heiliges op grond daarvan afgewys is, in sy teologie self ook so sterk met die skepping en verskeidenheid kon werk, ja selfs kon redeneer dat die kultureel-etniese verskeidenheid die enigste legitieme grond vir aparte kerke vir aparte volke is ${ }^{21}$ - dit was nie bevorderlik om die antitese tussen sy teologie en die volksteologie duidelik na vore te laat kom nie, al het hy self die dwalinge van die volksteologie besef en afgewys. As hy dan ook nog met 'n beroep op Stoker redeneer dat daar' $n$ verband tussen 'n volkse kerk en die volksiel bestaan ${ }^{22}$, en dat die bestaan van aparte volkse kerke dus voor-die-hand-liggend is, mak hy dit nog moeiliker vir homself om die kritiese afstand tussen homself en die volksteologie sigbaar te laat word.

\section{Die Skeppings- en Voorsienigheidswoord}

Dit bring my by 'n laaste vraag, naamlik of sy wysgerige denke vanuit die skepping hom nie daartoe gebring het om in sy teologie 'n te groot betekenis aan die algemene openbaring en die algemene genade te heg nie. Ek weet nie of ek hom hierin reg verstaan nie. Waar hy in sy Dogmatiek uitdruklik oor die algemene openbaring handel, sê hy niks anders as wat gewoonlik in die gereformeerde dogmatiek daaroor gesê word nie 23 . Maar vanaf sy boek oor die kerk onderskei hy in sy leer aangaande die Woord van God na die voorbeeld van Barth tussen verskillende gestaltes van die Woord 24 . Anders as Barth wat drie gestaltes van die Woord onderskei wat al drie met die besondere openbaring te make het - Heyns vind dit 'n soteriologiese versmalling - praat hy van ses gestaltes, waarvan twee myns insiens met die algemene openbaring te make het: die Skeppings- en die Voorsienigheidswoord. Dit is vir hom so belangrik, dat dit nie net in sy boek oor die kerk as noodsaaklike element voorop gestel word nie, maar ook in ander boeke, selfs tot in die heel jongste, herhaal word 25 .

Mag 'il mens hieruit aflei dat Heyns aan die algemene openbaring 'n baie betekenisvolle rol toeken, sodat daar volgens hom uit die skepping en die geskiedenis Woorde van God tot ons kom wat normatiewe betekenis vir ons het en ook ons verstaan van die geskrewe Woord van God kan bepaal? Hy self bring die 
Skeppings- en Voorsienigheidswoord nie uitdruklik met die algemene openbaring in verband nie. Hy praat graag daaroor as die krag van God waardeur Hy die skepping in aansyn geroep het en in sy onderhouding en regering dra en bewaar. Maar die term "Woord" wek tog die indruk dat God deur sy skepping en onderhouding met ons praat. Hy bring die Skeppingswoord dan ook uitdruklik in verband met die natuurpsalms wat tradisioneel as bewyse vir die algemene openbaring geld. Hy sê ook dat die Skeppingswoord nie net kreatief is nie, maar ook imperatief: wat is, moet wees ${ }^{26}$. En van die Voorsienigheidswoord kan hy sê: Inderdaad word Gods stem in die geskiedenis verneem, al is dit vermeng met menslike bygeluide ${ }^{27}$. Ek moet hieruit aflei dat ons in die geskiedenis dus tog met die algemene openbaring te make het wat vir ons normatiewe betekenis kan hê, mits ons dit reg verstaan. So kan Heyns in sy boek oor die kerk die verskeidenheid van volkere wat ons uit die Voorsienigheidswoord ken, normatief bepalend ag vir die idee van 'n veelheid van volkse kerke, al is hy uitgesproke daaroor dat dit nie geslote kerke mag wees nie ${ }^{28}$.

Nie net die algemene openbaring nie, ook die algemene genade kry egter by Heyns 'n sterk aksent (selfs al noem hy dit nie so nie). Dit kom onder andere daarin uit dat hy die nie-Christelike godsdienste hoog kan aanslaan. So kan hy byvoorbeeld in sy pleidooi vir 'n teologie van gehoorsaamheid 'n godsdiensfenomenologiese argument hanteer. Hy sê dat die kategorie van gehoorsaamheid vir alle godsdienste belangrik is, en meen dat dit daarom ook met die oog op die betekenis daarvan vir die Christelike godsdiens ondersoek behoort te word ${ }^{29}$. Dit sluit aan by ander uitsprake waarin hy waardering vir die algemene religiositeit kan openbaar en by aanhangers van ander godsdienste brokstukke van egte, legitieme gehoorsaamheid en dus boustene van die koninkryk aanwesig ag. Ook nie-Christene, sê hy, lewe uit Christus en sy genade en is dus in staat om ten minste iets te verwerklik van sy bedoeling met hierdie wêreld ${ }^{30}$.

Hierdie soort uitsprake wek by my die gevoel dat sy wysgerige inset meebring dat hy aan die algemene openbaring en algemene genade 'n baie meer positiewe betekenis toeskryf as wat ons in die gereformeerde dogmatiek gewoond is. Vanuit 'n magtige kosmiese visie op die gang van Gods koninkryk kan hy dan, met 'n beroep op Stoker en Dooyeweerd, sê dat die kerk, die prediking, die Bybel, ja selfs die begrip "Christelik" in die lig van die universele teenwoordigheid van gehoorsaamheidsgestaltes heilsaam gerelativeer moet word ${ }^{31}$.

\section{'n Helder geluid}

Die vrae wat ek aan die adres van Heyns stel, is egter nie my laaste woorde oor hom nie. Dit neem ook niks weg van my waardering vir en erkentlikheid teenoor hom nie. Dit is immers deel van die dramatiese werklikheid van ons geskiedenis dat juis hy een van die teoloë geword het wat sedert 1980 'n helder geluid laat hoor en 'n 
kragtige invloed op die verandering van koers in die Ned Geref Kerk uitgeoefen het. In die stryd wat hy in die tagtigerjare in die kerk moes stry, met al die bitterheid van 'n kerkskeuring wat daarmee saamgehang het, het Heyns ongetwyfeld moontlike misverstande wat deur sy eie teologiese posisies van vroeër gevoed kon gewees het, van die tafel gevee. Hy het vreesloos opgestaan vir wat hy as die gebod van hierdie uur verstaan het, en in dié proses beslis vir homself baie kritiek en gramskap op die hals gehaal. Dit kan nie betwyfel word nie, dat hy in hierdie jare 'n rol gespeel het waarvoor ons almal net die grootste waardering kan hê.

Ook wat sy teologiese werk betref, het hy egter vir my besef 'n duideliker kritiese snykant in sy werk gekry as wat vroeër die geval was. As 'n mens kyk na die wyse waarop hy in sy Teologiese Etiek II/2 oor die volksverband skryf en dit laat uitloop op 'n kritiese bespreking van apartheid en al die fasette daarvan, merk 'n mens dat jy in 'n ander atmosfeer as vroeër adem ${ }^{32}$. Waar hy vroeër apartheid as 'n bepaalde gehoorsaamheidsmodel beskou het, het dit vir hom later duidelik geword dat dit nie gehandhaaf kan word nie. Net so is wat hy in sy Inleiding tot die Dogmatiek oor die eenheid en katolisiteit van die kerk skryf33, vir my besef vry van die vroeëre sekerheid dat die volkereverskeidenheid tot 'n pluraliteit van volkse kerke moet lei. Daar is myns insiens reeds 'n sekere progressie in hierdie rigting sigbaar vanaf sy Dogmatiek na sy Etick $1 \mathrm{l} / 2^{34}$. Dit het my altyd gehinder dat hy nie genoegsaam vanuit die plaaslike kerk gedink het nie. Ek was altyd van mening dat die gereformeerde idee van kerkverband genoeg ruimte laat vir die diversiteit van kulturele en ander aard waarvoor Heyns gepleit het, sonder egter dat die eenheid van die kerk daardeur in gedrang gebring hoef te word. Gelukkig kon ons mekaar in die jongste jare ook hierin beter vind.

Afsluitend moet ek sê dat ek dit as 'n voorreg beskou dat ek Johan Heyns nie net geken het nie, maar dat sy pad en myne so ver saamgeloop het. Ons het ons verskille gehad, maar dit het ons vriendskap nie bedreig nie. Inteendeel, ons het in die loop van die jare mekaar steeds beter verstaan. En as ek met 'n persoonlike woord mag afsluit: Johan se spontaneïteit, sy broederlikheid, sy toegeneentheid, maar bowe-al sy brandende passie vir die saak van Gods koninkryk, sal my altyd bybly. Ek wens hom die allerbeste vir die toekoms toe!

\section{NOTAS:}

1 Lesing gelewer by geleentheid van die afskeid van professor J A Heyns op 28 Oktober 1993.

Dat dit vir my ' $n$ besondere voorreg en eer is om by geleentheid van my deurlugtige kollega en vriend se afskeid enkele woorde te mag sê, spreek vanself. Ons twee se weë het oor baie jare saamgeloop. 'n Geleentheid soos hierdie kan 'n mens dus ook nie onaangeraak laat nie. Daarom is daar vir my persoonlik ook iets pynliks aan verbonde, omdat dit per slot van rekening tog vir ons albei ook die einde van ons amptelike en openbare beroepslewe 
beteken.

Ek het vir die eerste keer van Johan Heyns gehoor by Wessel Oosthuizen by 'n CSV-kamp te Barberspan aan die einde van 1948. Hy het my vertel van sy slim klasmaat wat die volgende jaar vanaf Potchefstroom vir sy teologiese studie na die Universiteit van Pretoria sou kom. Ek het met die aanvang van die klasse in Februarie 1949 na Johan gesoek en ek onthou nog ons eerste kennismaking by die deur van die ou Senaatsaal, waarin ons destyds tydelik klas sou loop. Min het albei van ons op daardie oomblik besef hoe ons lewens in die toekoms nog vervleg sou wees.

Dit het al begin deurdat ons in ons BD-jare saam ingedeel is vir die mondelinge eksamens. Daaroor sou ek veel kon vertel, maar die tyd ontbreek. Na ons BD het ons albei in Nederland by Berkouwer gaan studeer. Johan het sy proefskrif voor myne klaar gehad. Ek het die voorreg gehad om hom vriendskaplik te opponeer by die promosie, waar sy eerste doktorsgraad cum laude aan hom toegeken is.

Terug in Suid-Afrika het elkeen van ons sy eie weg gegaan. Hy was in die Kaap en ek het my stryd in die Transvaal gestry. Maar ons was bestem om met mekaar saam 'n lang pad te loop en saam 'n sak sout op te eet, ondanks ons verskille in aard en temperament, ons aanpak en benadering van die teologie, en die verskillende keuses wat ons in die kerklike en maatskaplike lewe sou doen. Ek het al betreklik vroeg met die kerklike establishment in sy steun vir apartheid, en so ook onvermydelik met die Afrikanerestablishment self gebots en die prys daarvoor betaal. Johan het daarenteen al hoe meer aansien in kerklike en kulturele Afrikanerkringe verwerf. Sy benoeming as dosent in Stellenbosch en daarna as professor in Pretoria was voor-die-handliggend. Dat ek, na 'n draai in Kampen die plek kon inneem wat in Stellenbosch deur hom ontruim is, was 'n vreemde en onverwagte beskikking van God. Dit het meegebring dat ons vir die volgende meer as 'n kwarteeu saam die kerk op 'n bepaalde manier kon dien.

In hierdie tyd het ons mekaar eers werklik goed leer ken en ook nader na mekaar toe gegroei. Maar dit was tog eintlik eers in die tagtigerjare dat ons weë steeds meer gekonvergeer het, namate ook Johan al hoe meer verontrus geraak het oor die politieke situasie en bepaalde kerklike standpunte wat daarmee verband gehou het. In 1980 het ons albei die Hervormingsdaggetuienis onderteken. Voor die Algemene Sinode van 1982 het ons onsself daartoe verbind om te staan vir wat ons as die juiste weg vir die kerk gesien het, en ons het saam die smaad daarvan gedra. Maar die tyd was besig om te verander. Tot my vreugde is hy reeds in 1986 tot moderator van die Algemene Sinode verkies. Ondanks die verwerping wat hy van sekere groepe binne en buite die kerk moes verduur, het sy verbondenheid met die verligte Afrikanerelite meegebring dat hy 'n betekenisvolle rol kon bly speel. Daarby is hy 'n sterk mens, 'n vegter en optimis. Dit het hy van sy ouers, wat ek tydens my bediening in Potchefstroom as gemeentelede leer ken het, geërf. Dit beteken nie dat hy nie kan seerkry nie. Maar hy is nie kleinserig nie en het die vermoë om die kleinlike en die pynlike agter sy rug te werp en te doen wat volgens sy oortuiging reg is.

2 Vergelyk J A Heyns, Lewende Christendom, Kaapstad 1972, 49-50. 
3 Vergelyk J H Leith, "The Ethos of the reformed tradition", in: McKim, DK (ed): Major Themes in the Reformed tradition, Grand Rapids 1992, 5-8.

4 Vergelyk W Kreck, "Die Eigenart der Theologie Calvins", in: J Moltmann (hrsg), Calvinstudien 1959. Neukirchen 1960, 34-37.

5 Vergelyk G W de Jong, De theologie van dr GC Berkouwer, Kampen 1971, 13v; W D Jonker, "Dogmatiek en Heilige Skrif", in: Ex Auditu Verbi (Theologische opstellen aangeboden aan Prof Dr $G C$ Berkouwer), Kampen 1973, 86-111); J C de Moor, Towards a biblically Theological method, Kampen $1980,112 \cdot 120$.

6 Vergelyk J A Heyns, $a w, 69 \mathrm{v}$ en $96 \mathrm{v}$.

7 Vergelyk J A Heyns, Brug tussen God en mens, Pretoria 1973, 27v.

8 Kamphuis kapittel Heyns meermale oor wat hy as die invloed van Barth op hom sien, vergelyk J Kamphuis, Aantekeninge bij JA Heyns' Dogmatiek, Kampen 1982, 58,72 ensovoorts.

9 D F Theron, Die koninkryk van God in die teologie van JA Heyns. Doktorsproefskrif, UNISA 1984, 12,15.

10 Vergelyk A A van Ruler, "Het koninkrijk Gods en de geschiedenis", in: Verwachting en voltooiing, Nijkerk 1978, 29-42.

11 D F Theron, $a w, 52$.

12 Vergelyk sy Brug tussen God en mens, 30.

13 Vergelyk J A Heyns: "'n Teologie van gehoorsaamheid - ontwerp van 'n eietydse teologie", in: Ex Auditu Verbi (Theologische opstellen aangeboden aan G C Berkouwer) Kampen 1973, 84/85.

14 Vergelyk die titel van die feesbundel vir Heyns: C J Wethmar en C J A Vos (red), ' $n$ Woord op sy tyd, Pretoria 1988.

15 Vergelyk D F Theron, $a w, 48$.

16 Vergelyk D F Theron, $a w, 108$.

17 Vergelyk O Noordmans, "Critieke spanningen in de gereformeerde theologie", in: G Puchinger, Een theologie in discussie, Kampen 1970, 34-57.

18 Vergelyk G C Berkouwer, De triomf der genade in de theologie van Karl Barth, Kampen 1954.

19 As die beste geformuleerde voorbeeld van hierdie volksteologie (of apartheidsteologie) kan die dokument Geloof en Protes dien, wat in 1987 opgestel is as 'n antwoord van beswaarde lidmate van die Ned Geref Kerk op Kerk en Samelewing (1986). Geloof en Protes is opgestel en gepubliseer deur Die Voortsettingskomitee, Posbus 4776, Pretoria. 
20 J A Heyns, Die Kerk, Pretoria 1977, 206.

21 Vergelyk J A Heyns, Die Kerk, 216v.

22 Vergelyk J A Heyns, Lewende Christendom, 166-168; Die kerk, 209-219; Dogmatiek, Pretoria 1978, 379; Teologiese Etiek II/2, Pretoria 1989, 330-331.

23 Vergelyk J A Heyns, Dogmatiek, 7-11.

24 Vergelyk J A Heyns, Die Kerk, 9.

25 Vergelyk J A Heyns, Inleiding tot die dogmatiek, Pretoria 1992, 80-82.

26 Vergelyk J A Heyns, Die Kerk, 11.

27 Vergelyk J A Heyns, Die Kerk, 13-14.

28 Vergelyk J A Heyns, Die Kerk, 214-219.

29 Vergelyk J A Heyns, "'n Teologie van gehoorsaamheid - ontwerp van 'n eietydse teologie", in: Ex Auditu Verbi, 84-85.

$30 \quad$ J A Heyns, Lewende Christendom, 87.

31 J A Heyns, Lewende Christendom, 86-88.

32 Vergelyk J A Heyns, Teologiese Etiek II/2, Pretoria 1989, 39-75.

33 Vergelyk J A Heyns, Inleiding tot die dogmatiek, 328, 330-332.

34 Vergelyk J A Heyns, Dogmatiek, 379; Etiek II/2, 331. 